\title{
Alternative solid fuels combustion in small heat source
}

\author{
Michal Holubčík ${ }^{1, *}$, Nikola Kantová ${ }^{1}$, Jozef Jandačka ${ }^{1}$, and Zuzana Kolková ${ }^{2}$ \\ ${ }^{1}$ University of Zilina, Faculty of Mechanical Engineering, Department of Power Engineering, \\ Univerzitna 1, 01026 Zilina, Slovakia \\ ${ }^{2}$ University of Zilina, Research centre, Univerzitna 1, 01026 Zilina, Slovakia
}

\begin{abstract}
Air quality is related to the using of solid fuel based heat sources in which the human factor has a major influence on the quality of combustion, which can lead to higher emissions into the air. One of the negative factors is the use of alternative fuels in heat sources. The article deals with the combustion of various alternative fuels, on a waste basis, in small heat sources. There were tested 4 types of fuels: beech wood pieces, 2 types of solid alternative fuel on the base of municipal waste and wood waste. In the experiment, it was tested the influence of used fuel in the fireplace on the heat output, efficiency, production of gaseous emissions and particulate matter. The results confirmed that combustion of fuels not recommended by the heat source manufacturer reduces the efficiency of combustion and significantly increases all monitored emissions.
\end{abstract}

\section{Introduction}

Small heat sources are mostly used to provide thermal comfort in family houses, especially outside cities [1,2]. Paradoxically, in this out-of-town environment, air quality is rapidly deteriorating with the onset of cold weather. The media are increasingly reporting on the occurrence of smog situations and deteriorating air quality. This is related with the using of heat sources based on solid fuels where the human factor has a major influence on the quality of combustion, which can lead to higher emissions into the air [3, 4]. One of the negative factors is the use of alternative fuels in heat sources or often co - combustion of waste with standard fuels. These types of fuels are completely out as determined by the heat source manufacturer [5-7]. Incorrect operation of incomplete combustion heat sources leads to production of enormous emissions.

In 2014, according to the emission inventories in Slovakia, household heating accounted for up to $81 \%$ of total emissions of dust particles (PM2.5) and about $84 \%$ of pollutants of polyaromatic hydrocarbons (PAH) [8]. Dust particles of micro dimensions penetrate into lung alveoli and cause many respiratory and cardiovascular diseases. These particles are carriers of other harmful substances, benzo (a) pyrene (belongs to the group of substances -

\footnotetext{
*Corresponding author: michal.holubcik@,fstroj.uniza.sk
} 
PAH), which causes lung cancer, damages the liver, kidney and genetic information of cells [9-11].

The article deals about the combustion of various alternative fuels, namely beech wood pieces, 2 types of municipal waste and wood waste in the local fireplace - fireplace insert, testing the impact of the used fuel on heat output, efficiency, production of gaseous emissions and solid pollutants.

\section{Materials and methods}

\subsection{Used materials}

The following types of samples were used for combustion tests (Figure 1):

- Sample 1: Beech wood - air-chopped split wood in a length of about $45 \mathrm{~cm}$, moisture $12.24 \%$, combustion heat $17.168 \mathrm{MJ} / \mathrm{kg}$, heating $15.559 \mathrm{MJ} / \mathrm{kg}$.

- Sample 2: Solid alternative fuel with higher carton content - municipal waste - residual after separation of waste, humidity $10.78 \%$, combustion heat $16.077 \mathrm{MJ} / \mathrm{kg}$, calorific value $14.422 \mathrm{MJ} / \mathrm{kg}$.

- Sample 3: Solid alternative fuel with higher content of plastic - municipal waste - residual after separation of waste, humidity $3.2 \%$, combustion heat $17.307 \mathrm{MJ} / \mathrm{kg}$, calorific value $15.427 \mathrm{MJ} / \mathrm{kg}$.

- Sample 4: Wood waste - waste from forest dendromass processing in the form of chips, moisture content $9.8 \%$, combustion heat $17.582 \mathrm{MJ} / \mathrm{kg}$, calorific value $15.875 \mathrm{MJ} / \mathrm{kg}$.
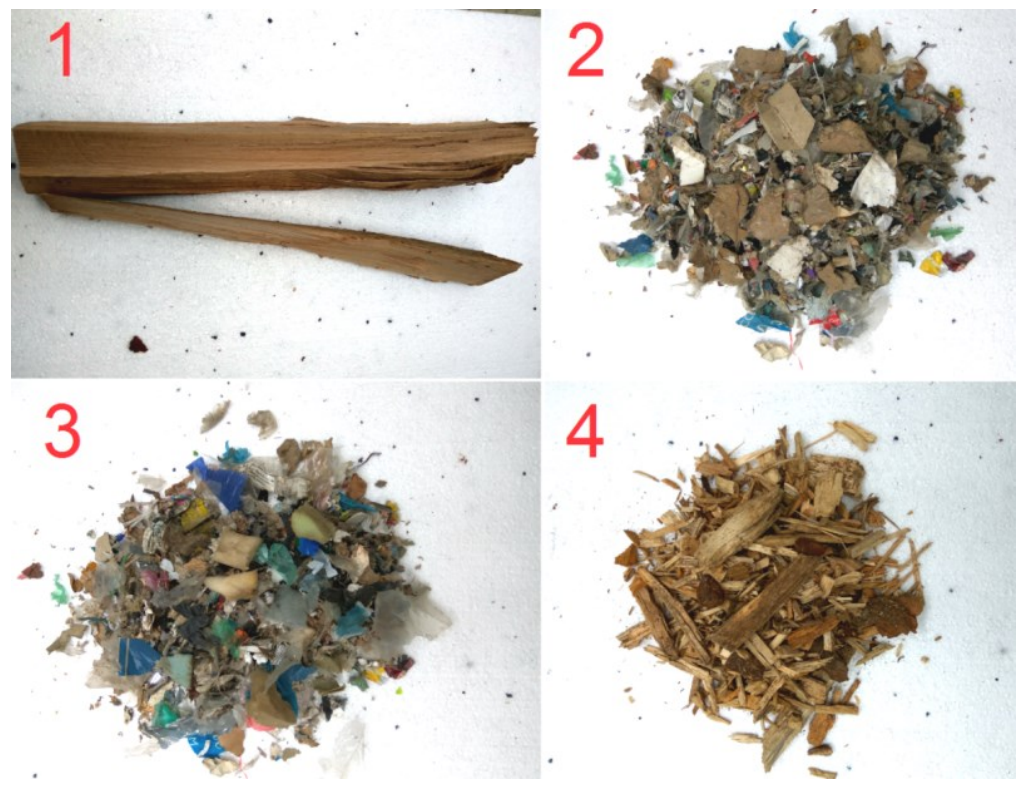

Fig. 1. Tested fuel type samples. 


\subsection{Methodology of experiments}

Experimental measurements to determine the influence of fuel type were made on a local heat source - fireplace insert with a rated thermal output of $13 \mathrm{~kW}$ (Figure 2) in accordance with STN EN 13229 "Inset appliances including open fires fired by solid fuels. Requirements and test methods" [12].

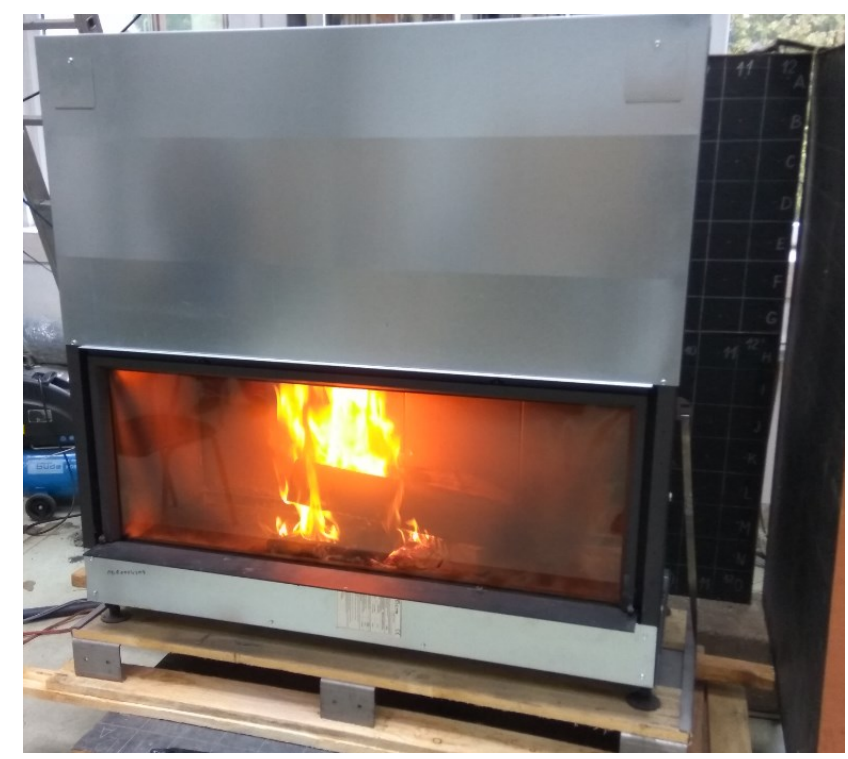

Fig. 2. Fireplace insert used as heat source for experiment.

Each sample was burnt three times in succession, and the results below are the arithmetic mean of these measurements. The combustion of each sample was carried out under the same conditions, the same setting of the combustion air supply and distribution, the same chimney draft $(12 \pm 2 \mathrm{~Pa})$, approximately the same temperature $\left(21 \pm 2{ }^{\circ} \mathrm{C}\right)$ and the relative humidity $(40 \pm 2 \%)$ of the ambient air.

The heat output $(\mathrm{P})$ and the efficiency $(\mathrm{I})$ of the fireplace insert were determined by calculation of indirect method in accordance with EN 13 229. Measurement of gaseous emissions, namely carbon monoxide (CO), nitrogen oxides (NOx), organic gaseous carbon (OGC), sulphur dioxide $\left(\mathrm{SO}_{2}\right)$, carbon dioxide $\left(\mathrm{CO}_{2}\right)$ and oxygen $\left(\mathrm{O}_{2}\right)$ were measured using an NDIR photometric sensor. Emission production values were converted to standard conditions $\left(0{ }^{\circ} \mathrm{C}, 101325 \mathrm{~Pa}\right.$ and $13 \%$ oxygen content in flue gas). The production of solid pollutants was determined by a gravimetric method in accordance with STN ISO 9096, provided that the isokinetic flue gas was observed. The chimney temperature and ambient temperature were determined using of K-type thermocouple (NiCr-Ni). The constant chimney draft was provided with a flue gas fan whose speeds were controlled by the frequency converter. These conditions are similarly to methods of other works $[13,14]$.

\section{Results and discussion}

The average values of measured parameters during experiments are shown in Table 1. 
Table 1. Average values of measured parameters during experiments.

\begin{tabular}{|c|c|c|c|c|c|c|c|c|c|c|}
\hline Sample & Test & $\begin{array}{c}P \\
{[\mathrm{~kW}]}\end{array}$ & $\begin{array}{c}\eta \\
{[\%]}\end{array}$ & $\begin{array}{l}\mathrm{O}_{2} \\
{[\%]}\end{array}$ & $\begin{array}{l}\mathrm{CO}_{2} \\
{[\%]}\end{array}$ & $\begin{array}{c}\mathrm{CO}_{13 \%} \\
{\left[\mathrm{mg} \cdot \mathrm{m}^{-3}\right]}\end{array}$ & $\begin{array}{l}\mathrm{NO}_{\mathrm{x}}, 13 \% \\
{\left[\mathrm{mg} \cdot \mathrm{m}^{-3}\right]}\end{array}$ & $\begin{array}{l}\mathrm{OGC}_{13 \%} \\
{\left[\mathrm{mg} \cdot \mathrm{m}^{-3}\right]}\end{array}$ & $\begin{array}{l}\mathrm{SO2}_{13 \%} \\
{\left[\mathrm{mg} \cdot \mathrm{m}^{-3}\right]}\end{array}$ & $\begin{array}{l}\text { TZL }_{13 \%} \\
{\left[\mathrm{mg} \mathrm{m}^{-3}\right]}\end{array}$ \\
\hline & 1 & 13.8 & 80.3 & 11.1 & 10.4 & 770.9 & 57.3 & 9.1 & 0 & 22.06 \\
\hline & 2 & 13.8 & 80 & 11.3 & 10.1 & 626.8 & 59.1 & 5.4 & 0.1 & 28.85 \\
\hline & 3 & 13.7 & 80 & 11.3 & 10.2 & 780.8 & 50.3 & 6.4 & 0 & 47.02 \\
\hline & Aver. & 13.8 & 80.1 & 11.2 & 10.2 & 726.2 & 55.6 & 7.0 & 0.0 & 32.7 \\
\hline & 1 & 8.7 & 50.6 & 18.1 & 2.5 & 1778 & 179.4 & 37.4 & 60.99 & 468.8 \\
\hline & 2 & 7.5 & 46.8 & 18.3 & 2.4 & 2148 & 156.8 & 47.9 & 57.4 & 397.6 \\
\hline & 3 & 8.3 & 49.6 & 17.9 & 2.8 & 1589 & 168.3 & 31.1 & 68.4 & 356.7 \\
\hline & Aver. & 8.2 & 49.0 & 18.1 & 2.6 & 1838.3 & 168.2 & 38.8 & 62.3 & 407.7 \\
\hline & 1 & 11.4 & 66.1 & 16.3 & 4.2 & 1664 & 233 & 28 & 41.91 & 241.3 \\
\hline & 2 & 11.2 & 65.8 & 16.5 & 4.1 & 1921 & 197 & 31.2 & 49.6 & 327.8 \\
\hline & 3 & 10.8 & 63.4 & 16.9 & 3.8 & 2119 & 166.7 & 38.1 & 55.3 & 297.3 \\
\hline & Aver. & 11.1 & 65.1 & 16.6 & 4.0 & 1901.3 & 198.9 & 32.4 & 48.9 & 288.8 \\
\hline & 1 & 9.8 & 56.1 & 16.9 & 3.9 & 2750 & 71.6 & 48.8 & 21.4 & 296.3 \\
\hline & 2 & 8.5 & 51.4 & 17.6 & 3.4 & 2846 & 59.3 & 53.3 & 18.1 & 181.3 \\
\hline & 3 & 9.6 & 57.2 & 16.5 & 5.1 & 1988 & 85.9 & 39.1 & 19.6 & 147.9 \\
\hline & Aver. & 9.3 & 54.9 & 17.0 & 4.1 & 2528.0 & 72.3 & 47.1 & 19.7 & 208.5 \\
\hline
\end{tabular}

The highest average heat output of the fireplace insert (Table 1) was as expected during burning the sample 1 - beech wood pieces which are the right fuel according to the manufacturer's recommendation of fireplace insert and reached an average of $13.8 \mathrm{~kW}$. All other fuel samples achieved lower heat output $(8.2 \pm 11.1 \mathrm{~kW})$. The heat output results corresponded to the efficiency values when the lowest value was recorded in the combustion of the solid alternative fuel with a higher carton content, which was, on average, more than $30 \%$ lower than the combustion efficiency during wood pieces burning. The percentage of oxygen $\left(\mathrm{O}_{2}\right)$ and carbon dioxide $\left(\mathrm{CO}_{2}\right)$ content in flue gas corresponded in accordance with EN 13229 with the efficiency of combustion of individual samples - the higher the efficiency of combustion, the lower the $\mathrm{O}_{2}$ concentration and the higher the $\mathrm{CO}_{2}$ concentration in the flue gas.

The production of all gaseous emissions was the lowest during combustion of beech wood pieces. The $\mathrm{CO}$ concentration during the combustion of solid alternative fuels was approximately 2.5 times higher in comparison with sample 1 . The highest production of CO was achieved during wood waste burning. The increased $\mathrm{CO}$ concentration was mainly caused by local incomplete combustion of samples 2, 3 and 4 were significantly worse than the wood pieces.

Production of nitrogen oxides (NOx), after conversion to $13 \%$ oxygen content in the flue gas, was the lowest in combustion of beech and the highest during waste with higher content of plastic burning. Similar results were recorded in the production of organic gaseous carbon (OGC) and sulphur dioxide $\left(\mathrm{SO}_{2}\right)$ which were significantly higher than during beech wood burning. 
The highest difference was recorded in the production of solid pollutants - particulate matter (PM) where alternative fuels had an approximately 6 to 12.5 times higher concentration of TZL in flue gases compared to the manufacturer's recommended fuel, lumber. It was also observed the colour difference of PM filters (Figure 3) during combustion of beech wood pieces (A) and alternative fuel with higher plastic content (C).

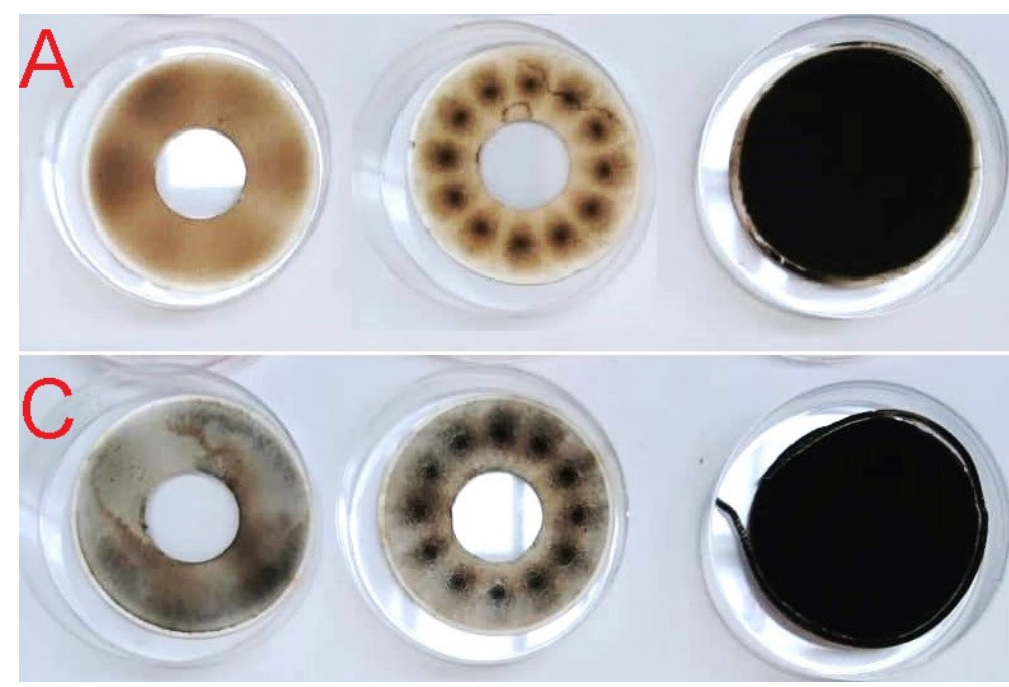

Fig. 3. The colour difference of PM filters during combustion of beech wood pieces (A) and alternative fuel with higher plastic content (C).

\section{Conclusions}

Due to the fact that small heat sources are among the largest air polluters this issue needs to be addressed to a sufficient degree. The most vulnerable from this point of view are the manually operated heat sources which also allow users to change their operation beyond the fuel changes.

The results have shown that combustion of alternative fuels, especially on the basis of waste, significantly increases the production of emissions, mainly particular solid pollutants. Also the results of thermal performance and efficiency showed that users of heat sources should only use the permitted fuels recommended by the producer of the heat source.

This work was supported by the projects APVV-15-0790 "Optimization of biomass combustion with low ash melting temperature", KEGA 046ŽU-4/2016 "Unconventional systems using renewable energy" and KEGA 033ŽU-4/2018 Heat sources and environmental pollution.

\section{References}

1. L. Soos, M. Kolejak, F. Urban, Biomasa-obnovitel'ný zdroj energie, Vert, (2012)

2. P. Chudíková, M. Taušová, K. Erdélyiová, P. Tauš, Potenciál dendromasy SR a jeho aktuálne využitie v tepelnom hospodárstve, Acta Mont., 15, 2, 139-145 (2011)

3. P. Križan, The densification process of wood waste, IMSETQM (2015)

4. L. Dzurenda, Model of heat load on the atmosphere by flue fases, Man. Tech., 15, 5, 804-808 (2015) 
5. J. Chabadová, Š. Papučík, R. Nosek, AIP Conf. Proc., 1608, 67-70 (2014)

6. M. Balas, M. Lisý, P. Kracik, J. Pospíšil, Municipal solid waste gasification within waste-to-energy processing, MM Sc. J., 2017, 1783-1788 (2017)

7. J. Pospíšil, M. Lisý, M. Spilacek, Adv. Mech. Eng., 8, 6 (2016)

8. L. Dzurenda, E. Hroncová, J. Ladomerský, Forests, 8 (1): 1-9 (2017)

9. J. Moravec, Increase operating life of active parts of Cold-Moulding Tools, Techn. Gaz., 24, 143-146 (2017)

10. M. Vantúch, K. Kaduchová, R. Lenhard, AIP Conf. Proc., 1745, (2016)

11. URL: www.vykurovanie.enviroportal.sk

12. STN EN 13229 Inset appliances including open fires fired by solid fuels. Requirements and test methods (2002)

13. T. Tomsej, J. Horák, S. Tomsejová, K. Krpec, J. Klanova, M. Dej, F. Hopan, Chemosphere, 196, 18-24 (2018)

14. Š. Papučík, R. Lenhard, K. Kaduchová, J. Jandačka, J. Koloničný, j. Horák., AIP Conference Proceedings 1608 (2014)

15. P. Nemec, M. Smitka, M. Malcho, Scientific world journal, 2014 (2014)

16. P. Nemec, M. Malcho, J. Jandačka, AIP Conference Proceedings, 1558, (2013) 